\section{B A Institute of \\ YK Business Administration \\ 六下 \\ Karachi \\ Leadership and Ideas for Tomorrow}

Business Review

Volume 5 Issue 1 January-June 2010

$1-1-2010$

\title{
Epistemic context of strategic decisions - interpreting the grammar of managerial praxis
}

\author{
Ahmad Raza \\ University of Management and Technology, Lahore, Pakistan \\ Hasan Sohaib Murad \\ University of Management and Technology, Lahore, Pakistan
}

Follow this and additional works at: https://ir.iba.edu.pk/businessreview

Part of the Business Administration, Management, and Operations Commons

\section{c) (7)}

This work is licensed under a Creative Commons Attribution 4.0 International License.

\section{Recommended Citation}

Raza, A., \& Murad, H. S. (2010). Epistemic context of strategic decisions - interpreting the grammar of managerial praxis. Business Review, 5(1), 149-158. Retrieved from https://doi.org/10.54784/

1990-6587.1262

This article is brought to you by iRepository for open access under the Creative Commons Attribution 4.0 License and is available at https://ir.iba.edu.pk/businessreview/vol5/iss1/10. For more information, please contact irepository@iba.edu.pk. 


\title{
ARTICLE
}

\section{Epistemic Context of Strategic Decisions: Interpreting the Grammar of Managerial Praxis}

\author{
Ahmad Raza \\ University of Management and Technology, Lahore, Pakistan \\ Hasan Sohaib Murad \\ University of Management and Technology, Lahore, Pakistan
}

\begin{abstract}
This paper makes a theoretical assertion that strategic decisions are deterministic and apriori cognitive programs, internalized by human actors through an epistemic context, generated by culturally contingent conditions. It is argued that, a pervasive worldview reverberates underneath the seemingly calm strategic attitude of the managerial leadership and, consequently shapes the grammar of managerial praxis. The leaders during their strategic engagements choose to decide on the basis of this deeply ingrained language of their respective worldviews, which have grown out of the collective symbolic knowledge of their respective societies. By analyzing three examples one each from society, economy and politics, which have become profoundly interlocked spheres of human societies in the unfolding millennium, we intend to demonstrate the validity of the foregoing assertion.
\end{abstract}

Key words: epistemic context, strategic decisions, worldview, grammar of managerial praxis.

\section{Prelude}

A main source of our failure to understand is that we do not command a clear view of the use of our words---- Our grammar is lacking in this sort of perspicuity. A perspicuous representation produces just that understanding which consists in 'seeing connexion'.Hence the importance of finding and inventing immediate cases.

The concept of a perspicuous representation is of fundamental significance for us. It earmarks the form of account we give, the way we look at things. Ludwig Wittgenstein

One step forward, two steps backward. Old Chinese saying on strategy 
Patience brings the object of desire, not haste. Have patience--- and God knoweth best what is right. Jalal-ud-Din Rumi

What is the sound of water falling? Zen koan

No one tests the depth of a river with both feet. Ashanti proverb

\section{Pre (Text) and Fore (Word)}

In the Philosophical Investigation, Ludwig Wittgenstein has placidly remarked that, "a picture has held us captive", thereby showing us the power of the words, we employ to communicate our understanding of the events occurring around us. We may never achieve a perspicuous representation in full of what we feel and experience around us, nonetheless, we learn to respond to words, concepts and situations the moment we learn the language in which everything is embedded. Language contains in its fold the follies and aspirations of the culture which shape and contextualize our view of the world, which we follow, observe and at times obey with incommunicable deep emotions. This deeper attachment to linguistic programmes; worldviews--- are held as a priori cognitive truths by a person which enable him to express himself and communicate with the rest of the world. These worldviews create a fundamental epistemic context for the persons trained and rooted in the cultures of which they are part and parcel. Cultures as manifested in these worldviews---or linguistic programmes--- outline the broader cultural paradigm by which habits, actions, behaviors and functions are made into meaningful social patterns. The notion of culture as shaper and programmer of human cognitive structures have been fairly established by the works of Hofstede (1993) and Berland (1986). The sway of culture over the thought patterns is so pervasive and well entrenched that individuals ordinarily are reluctant to use the words and concepts, employed and rooted in a different fundamental epistemic context than their own. Our ability to solve problem, take decisions, understand good and bad, establish interpersonal relationships, make friends and foes are all reflections of our a priori fundamental epistemic context duly conditioned by the language of the worldviews in which we are embedded by the command of nature.

What is so captivating about strategy and strategic decisions that demand our attention and how they are used in different epistemic (fundamental) contexts of West European worldview and its counterpart Islamic Eastern worldview? The dominant discourse on strategy and strategic decisions in the Western worldview is grounded in the Cartesian 'cogito', portraying the former as rational calculi, which can be mastered and applied by the persons to arrive at decisions or solve problems encountered by them. It is morally justified(and justifiable),so long as it can lead to measured and tangible consequences, in terms of profits,gains,pleasures and victories, both in personal and social context. The legitimacy of the actions taken in lieu of this portraiture largely resides in the 'cogito' without any manifest regard for any supra rational entity such as 
God, outside the explainable domain of causality. The linguistic programme of Cartesian cogito, presents us with a picture of decisions as rationally determined course of action, justified by an a priori moral logic mutually agreed upon by all the human actors, involved in the social relationship. Decisions in different spheres of life such as politics, economics, society, and ethics are causally and rationally constructed, and humanly legitimized social nomenclatures. If we try to formulate the logical picture of the decisions in the West European epistemic context, it would appear something like this:

\section{Figure1:}

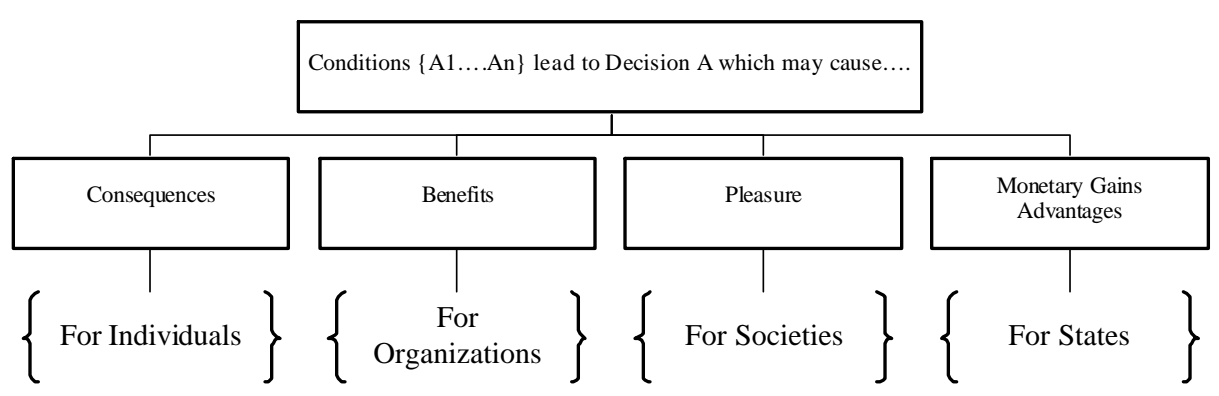

Decisions whether 'ordinary' or 'strategic', seen in the perspective of fundamental epistemic context of Cartesian linguistic programme--- worldview--- are causally and rationally determined individual and collective choices, courses of action, plans, agendas, programmes; all invoke the similar image. The general form of the decision is: it 'must' produce advantage. The human actors are morally justified to take decisions which give them advantage over other human actors. The justification of advantage, benefit, profit and pleasure comes from within the epistemic context itself and not from any outside authority. The outcome of the decisions (strategic or ordinary), success or failure, advantage or disadvantage, rising profits or declining market share, a battle victory or defeat; all are attributed to human actors, in short human actors take a certain decision and is eventually held responsible for its consequences, either bad or good.

Several researchers have shown that strategy formulation and strategic decisionsmaking are based on rational calculi of the 'conditions' which if causally understood can lead to effective and competitive decisions concerning different managerial states of affairs. They perceive strategic decisions as objective structures formed out of the independent, autonomous human cogitio. The plausible application of human cogitio as a ground of decisions- making process, based on objectivity and universality can lead to useful business profits and financial gains by the human actors. Those who cannot see the causal connexion of strategic decisions and their competitive advantages are left to wither away and consequently are not fit for the business, politics and economics games.Strageic decisions are, therefore, in the Cartesian worldview, appear to us as 
rational operators controlling, steering, maneuvering and predicting the human environments as observed in economic, social and political milieus for justified advantages for all human actors. A decision must lead to rationally calculable and predictable scenarios based on the causally observable facts, conditions or forces which should lead to effective and desirable consequences (Porter, 1979: Filbeck etal, 1996: Larson etal, 2004 and Baldridge etal, 2004).

Sometime strategic decision does not lead to rationally calculated competitive advantages and useful monetary gains. We come to hear that thousands of businesses go bankrupt, only in U.S alone despite the best formulated business strategies (Hitt etal, 2003), politicians lose elections and social agendas fail. There may be something deeper and complex which may be influencing the success or failure of decisions. Those who criticize cogitio as an independent and objective tool of strategy formulation and strategic decision-making, therefore, invoke social,environmental,economic and cultural 'contexts', which may influence the former (Mintzberg,1994;Curcioetal, 1996; Hall, 1998; Liljenquist, 2004). Nonetheless, even in the contextual approach to strategic decisions we are not freed from the tight nose of cogitio. It simply undergoes an interpretative twist. Now strategic decisions are perceived in the rainbow of socio-culturally constructed rationalities. For them strategic decisions are not just manupilative, reversible, rational structures, which generate tangible and competitive advantages for the human actors; on the contrary these are socio-cultural legitimacies, relativistic and irreversible, given the context in which they become operational and effective. They contend that the cogitio of strategic decisions is context-bound and may make sense or relevance within that context. Strategic decisions are no more pictured as universally valid cogitio operators; rather these are culturally legitimized operators, which may hold different meanings for different human actors engaged in it. Some sort of humanness and responsibility can be noticed in such a grammar of strategic decisions. Failure or success of strategic decisions may be attributed to, in a contextually validated cogitio, to some sort of freakish behavior of the actors driven by cultural, social and environmental conditions. Cogitio as an instrument of ascertainable strategic decisions or strategy formulation remains in the backdrop with an interpretative twist of contextuality, relativity and locality.

We can also see another 'picture' of interpretative twist of cogitio in the writings of 'postmodern' writers (Ezzamel and Wilmot, 2004). Cogitio is present in the critique of strategy and strategic decisions; but in a different garb. Having criticized the 'strategic' and 'strategy' both in its rational and contextual paradigms, they contend that it (strategic decision) is located in the 'constitutive' structure of the relationships, in which these operate. Power, knowledge and society are interspersed in the textualities of human actors (Foucalt, 1967). These textualities demonstrate the labyrinth of complexities, insights, attitudes, emotions which might be at work. Cogitio of decisions is not free and independent, rather a plethora of texts and discourses make it both transparent and ambiguous simultanesoly. The significance of (un)strategic decisions is thinly disguised by the interplay of multiple layers of interactions of human actors as unfolded through 
the textual constitution. But can we make a sense of 'constitutive' nature of textuality of the strategic decisions without having recourse to the dominant linguistic programme of the West---the cogitio.We contend that even seen as constitutive textuality of relationships; the understanding of the strategic decisions do not liberate itself from the hold of the cogitio-as an effective instrument of valid and advantageous activity. Strategic decisions are just pictured differently with a new interpretative understanding. The fundamental epistemic contexts of decisions, however, remain firmly rooted in the linguistic programme of the Cartesian cogtio.

Now let us 'see' how decisions, 'ordinary'as well as 'strategic' are carried forward in a different yet fundamental epistemic context of the linguistic programme-- worldview of Islamic Eastern society. Here decisions are firmly rooted in the epistemic context of faith (Iman).The moral intentions and spiritual consequences of the strategy formulation and strategic decision are deeply considered by the society. Moral and spiritual consequences of strategic decisions and their human cost are considered foremost instead of some monetary or political gain are considered for most in the decisions strategies. Profit, benefit, gains, advantages in business, politics and economy are circumscribed by morally and spiritually predefined patterns of behavior prescribed by God himself through his revealed word in the Quran. You cannot sell a product just because it would give a competitive advantage over the rivals in the marketplace, and consider yourself as justified by the cogitio to do so; moral and spiritual considerations as commanded by the God must be pondered in length before you make a decision for selling or buying. Decisions both ordinary and strategic have profound and serious human consequences. Therefore they must conform to the Revealed limits, lest they incur any collective or personal damage to human stakeholders affected by them. Advantage lies not in the tangible gains but in the moral commitment and spiritual principles implicit in such an engagement. The epistemic context is provided by the, 'religious experience' (Iqbal, 1982) and not the scientific theories espoused by human actors. Words, in this perspectivem are not merely 'pictures' of relationships or potpourri of mutually consented games; they are, as a Muslim mystic of $13^{\text {th }}$ century Mevlena Rumi said 'bowls who carry the water of meaning in them. Every word and its usage have an emotional and moral consequence for its users, therefore should be used carefully and sensibly. They are enlivened by the spiritual and emotional experience of mankind. Consequently, they possess a substantive semantic life, which is to be respected own its on. Given this statement, we contend, therefore, that strategy formulation and strategic decision making is completely shaped by the wisdom of the strategist and decisionmakers.

Strategic decisions and strategy formulation in the epistemic context of faith are the sole arbiter of human praxis and testing ground for moral efficacy of diverse activities, they are seen as spiritually and morally advantageous structures of choices. This is so, because God himself is the, 'Best of all strategists', and knows in his vastness the minutiae of stratgems, games, deceptions and speculations of the human actors about 
their materialistic competitiveness. The individuals as well as groups are therefore advised to make morally valid decisions in all walks of life as prescribed in the Revealed Word. They should aim at the humanistic interest foremost, while engaging in multiple strategic scenarios in social, political and economic fields. Strategic decisions are centered on the notion of distributive justice, instead of competitive justice; wherein cogitio is let loose on the basis of Benthamite utilitarian morality to advance its materialistic benefits, market shares and political power. God being the creator of men desires from them such formulation of strategy and make such decisions that promote the collective spiritual and moral growth of the entire mankind.

\section{Figure2:}

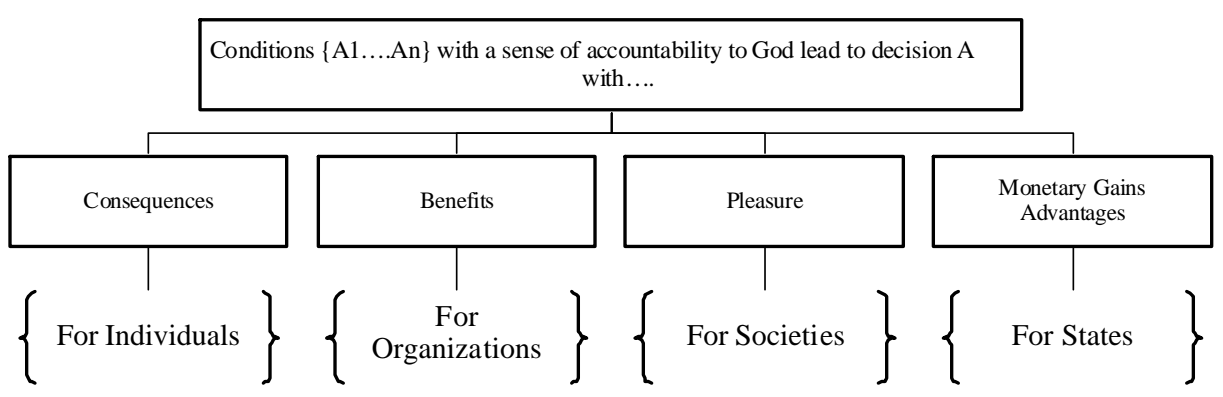

In the daily cultural life, strategic decisions are taken in, 'collective consultations'. Consensus, persuasion, participation and patience are some of the preferred ways of doing things; wherein due moral consideration is given to the human consequences of strategic decision making process. The cogitio of managerial praxis is tempered by a sense of spiritual and moral accountability of all actions taken and all decisions enacted in practice. Material, economic, political and business gains are to be balanced in relation to the emotional and spiritual needs of the human societies. Seldom are those decisions perceived as good by the Muslim society which are offensive, aggressive, individualistic and which overlook the humanistic costs of such actions and decisions. This is so, because all human beings are creatures of God, who have an equal and natural stake in the world resoures, which are to be shared, distributed and circulated, with a mutual trust and not to be possessed,owned,exploited and controlled selectively and competitively on any grounds space ,racial,ethnic,military,economic or political.

In the light of foregoing discussion, we now intend to demonstrate how strategy and strategic decisions are unfolding themselves in the ensuing millineum. Three issues have clearly emerged which would continue to attract the attention of diverse human societies. These are (1) the issue of human gene cloning, (2) the issue of globalization, and (3) the issue of terrorism. We shall discuss them one by one. 


\begin{tabular}{ll}
\hline Business Review - Volume 5 Number 1 & January - June 2010 \\
\hline
\end{tabular}

\section{Human Cloning}

The most crucial moral question faced by the western societies has been posed by the advance reproductive technologies (Scheffer, 2003). How far and how much human beings should intervene into the natural systems of family and kinship, have assumed a major moral and social debate in North America and Western Europe. How forces of genetic engineering are to be managed and where the final line is to be drawn? Abortion, IVF (Invitro fertilizations) and human gene cloning are shaking both the leaders and the laymen. The opinion is divided on the moral and social consequences of the genetic engineering. Noetheless, it remains within the fundamental epistemic context of cogitio. The strategic decision whether to continue or stop meddling into the natural basis of human culture and society are to be made by the human reason and not to be restrained by some uniform and universal spiritual morality. In Islamic East, everything related to 'genetic' is perceived with suspicion, reserve, and alarm. In principle no human agreement can rationally intervene into the moral and spiritual foundation of human identity with the only exception of medical acuteness and lifesaving reason. The institution of marriage and human reproductive methods are sacred and cannot be altered on any grounds. However, utilization of technological intervention into the institution of family, marriage and reproduction with an expressed aim to support the protection of such processes and activities which promote the collective spiritual health of the individuals, is considered valid and justified. The Quranic admonition that, if ye save the life of one man, that means ye have saved the whole mankind', provides solid moral basis for protecting and promoting the human life as it is. We can clearly see the underlying worldviews of both the Western and Eastern Muslim epistemic context so far as the management of genetic engineering is concerned and how the issue is perceived in both the cultural traditions.

\section{Globalization}

The MNCs' (Multinational Corporations) have become a major carrier of globalization of world economies (Deresky, 2003). The national economic systems are rapidly being swayed into a globalized economic order. Although there has been a steady demand for a transparent global economic system and increased emphasis on the ethical and social responsibility indicators of the global businesses, nonetheless the management literature is replete with the greed and excesses of the organized corporate crime (Deresky, 2003). It seems that under the flag of MNCs' and globalization, exploitation of the national and local economies have entered into the new era of worldwide economic colonization. We venture to add that if globalization has to survive as a viable business strategy in the coming months and days, it must take into serious consideration the human and spiritual dimension. The dominant global corporations emanate either from Europe or North America and they want a 'free' ground for business and trade. This has caused widespread concern in most parts of Asia, Middle East and Latin America.' 
Globalize' or 'Spiritualize'; the answer depends largely on how we decide and from which epistemic context we approach the issue.

\section{Terrorism}

The post 9/11 world is a 'world of America', said President Bush following attacks on Twin Towers in New York. In this world major political issue is terrorism which threatens the security of the United States, therefore, she has every right to strike 'preemptively' anywhere in the world to root out this menace (Hermann and Keller, 2004). If your reason tells you that there is sufficient evidence that your neighbor is planning to murder you; forestall him and kill him instead. Kill the enemy in advance. This is simple mathematics. It has serious consequences both for the international system and the people all around the world. It has become an unpredictable and insecure world. Whatever American perceptions on terrorism and AlQeada are; its political strategy needs due consideration by all concerned. America has engaged whole Muslim populations into the war against terror. The whole political rhetoric smacks of the Medieval Crusades. The logic of cogitio is so vibrant and manifest that it has put the world peace and security in jeopardy. This needs to be seen in differently, if we want to make this world safer for people, for globalization and for sustainable development. Instead of a 'clash of civilizations' (Huntington, 1993), both Western societies and Islamic Eastern societies need to establish 'mutual harmonies' (Iqbal, 1982) and come out of the medieval fixity of crusades and prosper together for the common and collective responsibility of global peace and harmony.

\section{References}

Baldrige, D.C.Floyd, S.W and Markoczy, L. (2004), “Are managers from Mars and Academicians from Venus? Toward an understanding of the relationship between academic quality and practical relevance". Strategic Management Journal.Vol.25, issue 11, pp 1063-1074.

Berland, J. (1985), No Five Fingers Are Alike; Cognitive Amplifiers in a Social Context. Massachusetts. Harvard University Press.

Curcio, Richard.J. (1996), "Corporate Environmental Strategy: Impact upon firm value”. Journal of Financial and Strategic Decisions. Vol.9 No.2 Summer 1996.Retrieved on 11/02/04.http://www.studyfinance.com/jfsd/jv11

Deresky, H. (2003), International Management; managing across borders and cultures. Prentice Hall. New Jersey.

Filbeck, G; Gorman, R. F. and Preece, D.C. (1996), "Behavioral Aspects of the IntraIndustry Capital Structure Decision”. Journal of Financial and Strategic Decisions. Retrieved on 11/02/04. 
Ezzamel, M.and Wilmot.H. (2004), "Rethinking Strategy: Contemporary Perspectives and Debates". European Management Review.2004, 1, 43-48, http://palgravejournals.com/emr

Foucault, M. (1970), The Order of Things; Archaeology of Human Science.Tavistock Publishers. London.

Hall, P. L.and Rieck, R. (1998), "The Effect of Positive Corporate Social Actions of Shareholder Wealth". Journal of Financial and Strategic Decisions. Retrieved on 11/02/04.Vol.11, No 2,1998.http://www.studyfinance.com/jfsd

Hermann, R.and Keller, J. W. (2004), "Beliefs, Values and Strategic Choice: US Leaders; Decisions to Engage, Contain and Use Force in an Era of Globalization".

The Journal of Politics. Vol 66,1ssue 2, 2004.ret.on11/15/04.http://www.blacwellsynergy.com

Hitt, M.A; Ireland, D.R.and Hoskisson, R.E. (2003), Strategic Management; Competitiveness and Globalization. Thomson South Western Publishers.U.S.A.

Iqbal, M. (1982), The Reconstruction of Religious Thought in Islam. Sh.M.Ashraf and Sons Publishers.Lahore.Pakistan

Liljenquist, K.A, Galinsky, A.D. and Kray, L.J. (2004), "Exploring the Rabbit Hole of Possibilities by Myself of with My Group: The Benefits and Liabilities of Activating Counterfactual Mindsets for Information Sharing and Group Coordination". Journal of Behavioral Decision Making.Vol.17, Issue 4, pp263-79.

LarsonJr, J., R.Sargis, E.G.and Bauman, C.W. (2004), "Shared Knowledge and Subgroup Influence During Decision Making Discussions". Journal of Behavioral Decision Making. Vol.17.Issue 4, pp 245-62

Mintzberg, H. (1994), "The Fall and Rise of Strategic Planning". Harvard Business Review.Jan-Feb.107-114.

Porter, M. (1979), "How Competitive Forces Shape Strategy". Harvard Business Review. 57 (2):37-145.

Rumi,Jalal-ud-Din. (1985), The Mathanvi .Tr by, Reynold, A Nicholson. Kazi Publications Lahore. Pakistan.

Schaeffer, Richard, T. (2002), Sociology. MacGraw Hill. Boston.

Wittgenstein, L. (1981), Philosophical Investigations. Trs.G.Anscombe and Von Wright. Basil Blackwell. Oxford. 
F.W. Taylor's Four Principles of Scientific Management

1. Scientifically study each part of a task and develop the best method for performing the task.

2. Carefully select workers and train them to perform the task by using the scientifically developed method.

3. Cooperate fully with the workers to ensure that they use the proper methods.

4. Divide work and responsibility so that management is responsible for planning work methods using scientific principles and workers are responsible for executing the work accordingly.

Kathryn M. Bartol \& David C. Martin Management 